\title{
Is there direct evidence for late Quaternary collapse of the West Antarctic ice sheet?
}

\author{
LLOYD H. BURCKLE \\ Lamont-Doherty Earth Observatory, Pallisades, New York 10964, U.S.A.
}

\begin{abstract}
By studying diatoms recovered from sediment taken from beneath the West Antarctic ice sheet (Ice Stream B), Scherer (1991) concluded that this feature must have collapsed at least once during the past 600 kyear and that the two likely candidates for time of collapse were oxygen-isotope stage 11 (362-423 kyear BP) and sub-stage $5 \mathrm{e}$ (110-128 kyear BP). This conclusion does not stand up to critical examination of the data, however. Specifically, the diatom datum level, the last occurrence of Actinocyclus ingens, used to constrain the 600 kyear date is diachronous into higher latitudes and does not apply in sediments recovered from near Antarctica. Secondly, the additional diatoms used to constrain the time of collapse to the late Quaternary either range before the late Quaternary or have no published geological record. In spite of this, there are data to suggest that one or more late Quaternary interglacial intervals were as warm as, or warmer than, the present. As yet, however, no direct evidence exists to incorporate a West Antarctic ice sheet collapse into these scenarios. It is suggested that this debate is best resolved by study of deep-sea sediments of late Quaternary age recovered from around the Antarctic continent.
\end{abstract}

\section{INTRODUCTION}

Direct evidence of past changes in areal extent of small ice sheets (i.e. the Greenland or West Antarctic ice sheets) is difficult to obtain. Three basic approaches have been taken in documenting past stability (or instability) of such features: (1) study of sediments (primarily microfossils) recovered from beneath present ice sheets; (2) study of the effects that changes in ice sheets (i.e. draw-down; buildup) may have had globally; (3) oxygen-isotope analysis of ice cores. With the possible exception of point 3 , these approaches are attended by problems; the former by the fact that subglacial sediments have been smeared and/or re-worked by subsequent glacial activity and the latter by the fact that any observed climatic signal (e.g. sea-level rise, change in $\delta^{18} \mathrm{O}$ ) cannot be directly attributed to a specific ice sheet. Furthermore, the measurements are such that volume changes in small ice sheets such as the West Antarctic ice sheet frequently cannot be detected above noise level. This is particularly true for changes in $\delta^{18} \mathrm{O}$ recorded in deep-sea sediments but may also be true for the sea-level record older than the Holocene. Where the climate signal is recorded in continental sediments older than latest Quaternary, there are the additional problems of dating the event and correlating it to the deep-sea record.

Nevertheless, there is some urgency to understanding past behaviour of small ice sheets. This is particularly true for the West Antarctic ice sheet which is marine-based and considered vulnerable to even a small rise in sea level (Mercer, 1978). Extreme global-warming scenarios proposed for the next century might provide the sea- level trigger leading to collapse of this ice sheet. Under these circumstances, one must understand the dilemma faced by the glaciological community; they are charged with predicting the future behaviour of this ice sheet, while knowing very little about its past behaviour (i.e. during glacials and previous interglacials). Specifically, they need to know (1) if it collapsed at any time during the late Quaternary (0.78 Myear to present), and (2) if collapse did occur, what was the paleoenvironmental and/or physical setting which accompanied it?

In a recent paper, Scherer (1991) claimed to provide the necessary direct evidence that collapse occurred during the late Quaternary. He noted that "... the occurrence of late Pleistocene diatoms beneath the West Antarctic ice sheet provides the first direct evidence that this marine ice sheet had collapsed and reformed since its initial development". I take issue with this conclusion. I should point out that I do not dispute the possibility of collapse during the late Quaternary but rather with the direct evidence presented by Scherer (1991). The reader will note that I am laboring under the assumption (as did Scherer (1991)) that the stability of the West Antarctic ice sheet is compromised during warm time intervals (i.e. interglacials). Please note, however, that Domack and others (1991) have presented field data suggesting that ice sheets may grow during warm intervals, and MacAyeal (1992) has presented numerical data suggesting that the West Antarctic ice sheet may have collapsed on an irregular time-table resulting from a dissimilarity in timescales between two different forcing mechanisms: Milankovich forcing and the aperiodic behavior of ice sheets overlying deformable beds. 


\section{IS THERE DIRECT EVIDENCE FOR COLLAPSE OF THE WEST ANTARGTIC ICE SHEET DURING THE LATE QUATERNARY?}

Scherer (1991) studied diatoms in tills recovered from beneath Ice Stream B, a fast-moving glacier which feeds into the West Antarctic ice sheet and which is bounded on all sides by stagnant or slow-moving grounded ice. In his analysis of the diatoms recovered from sediments at the grounding line, he made note of the following: the diatom, Actinocyclus ingens, is a well-established stratigraphic marker in Southern Ocean Quaternary sediments. In paleomagnetically dated sediments from Antarctic and sub-Antarctic regions, it disappeared in the early part of the Brunhes magnetic chron at about 620 kyear BP (Donahue, 1967; Abbott, 1974; Cielsielski, 1983) and was assumed to have disappeared at about the same time in sediments closer to the Antarctic continent. Using these and other data, Scherer (1991) reasoned as follows: the absence of Actinocyclus ingens in sediment samples from beneath Ice Stream B indicates that this region was largely ice-covered at least until about 600 kyear BP. Additionally, the absence of typical Middle and late Pliocene stratigraphic markers further argues that this region was ice-covered during most of the Middle Pliocene to early Quaternary up to about 600 kyear BP or even later. Finally, he noted the presence of rare diatoms which he indicated were late Quaternary in age. Combining these observations with paleoclimatic data collected elsewhere, he concluded that the West Antarctic ice sheet must have collapsed at least once during the past 600 kyear and that the two likely candidates for time of collapse were oxygen-isotope stage 11 (362-423 kyear BP) and sub-stage 5e (110-128 kyear BP; the c. 600 kyear date is taken as the maximum possible age for collapse of the West Antarctic ice sheet).

There is evidence, based on both continental and marine data sets, which points to a number of interglacial intervals during the late Quaternary which were possibly warmer than the Holocene. However, except for $\delta^{18} \mathrm{O}$ records covering the last glacial cycle in Greenland ice cores, they make no comment on the impact of such warming on high-latitude ice sheets. Therefore, if one focuses strictly on the evidence from diatoms recovered beneath Ice Stream B for West Antarctic ice sheet collapse, there are several problems with the conclusion that there is direct evidence that this feature collapsed within the past 600 kyear:

(1) There are no hard data to indicate that $A$. ingens became extinct at c. 600 kyear in sediments recovered from near the Antarctic continent. Indeed, the evidence suggests that it disappeared from waters near this continent much earlier. Consider the Weddell Sea region: in Ocean Drilling Program (ODP), leg 113, hole $690 \mathrm{~B}\left(65^{\circ} 09.63^{\prime} \mathrm{S}, 01^{\circ} 12.30^{\prime} \mathrm{E}\right)$ the last occurrence of this species is in Upper Pliocene sediments. In hole $693 \mathrm{~A}$ $\left(70^{\circ} 49.9^{\prime} \mathrm{S}, 14^{\circ} 34.4^{\prime} \mathrm{W}\right)$, it is rare in five samples and absent from all others in sediments ranging from Middle Pliocene to Quaternary. In ODP hole $695 \mathrm{~A}\left(62^{\circ} 23.5^{\prime} \mathrm{S}\right.$, $43^{\circ} 27.1^{\prime} \mathrm{W}$ ), it is rare in five samples, present in one and absent from all other samples in sediments ranging in age from Middle Pliocene to Quaternary. In ODP hole 696A $\left(61^{\circ} 50.9^{\prime} \mathrm{S}, 42^{\circ} 56^{\prime} \mathrm{W}\right)$, it is rare in one sample and absent from all others in sediments ranging in age from Middle Pliocene to Quaternary. In ODP hole 697B (61 $48.6^{\prime} \mathrm{S}$, $40^{\circ} 17.3^{\prime} \mathrm{W}$ ), it occurs up to the Middle Quaternary but is about 300 kyear short of the 600 kyear mark. All samples above the last occurrence of this species in this hole are barren of diatoms (all data noted above are from Gersonde and Burckle (1990)). In ODP sites occupied in the Indian sector of the Southern Ocean, $A$. ingens disappeared from the record during the late Quaternary in sections recovered north of about $61^{\circ} \mathrm{S}$ but to the south of this latitude they disappeared much earlier in time (Baldauf and Barron, 1991; Harwood and Maruyama, 1992).

There is additional evidence from the literature that the $A$. ingens last appearance is diachronous between the sub-Antarctic zone and the high-latitude Antarctic zone (i.e. that its last appearance is earlier nearer the continent). Donahue (1967) studied Quaternary diatoms in paleomagnetically dated piston cores recovered from the Pacific sector of the Southern Ocean. In cores taken north of $60^{\circ} \mathrm{S}$, the last abundant occurrence of Actinocyclus ingens is at about 600 kyear (please note that the last occurrence datum for this species is a last-abundant occurrence datum). However, in cores taken south of approximately $60^{\circ} \mathrm{S}$, the temporal occurrence of this species is very sporadic and one cannot pick its last stratigraphic occurrence (i.e. the last abundant occurrence datum; Donahue, 1967, figs 2 and 3). Ablemann and others (1990) noted that $A$. ingens was present (40$60 \%$ of the total assemblage) in the Weddell Sea in the time interval 1.7-0.7 Myear. However, they cited mostly sediment cores from north of $60^{\circ} \mathrm{S}$. The one core to the south of $60^{\circ} \mathrm{S}$ that they did cite (core 1458; 64 $4^{\circ} 59.34^{\prime} \mathrm{S}$, $01^{\circ} 51.02^{\prime} \mathrm{E}$ ) has few diatoms in that interval; in fact, the presumed late Pliocene to Recent interval in core 1458 is a biogenic carbonate (Ablemann and others, 1990, fig. 5). If a 620 kyear date for the last occurrence of $A$. ingens cannot be supported in sediment cores recovered from near the continent, then the absence of this species from sediments recovered from beneath Ice Stream B cannot be used to constrain the age of collapse of the West Antarctic ice sheet.

(2) In order to buttress the argument that there was a late Quaternary break-up of the West Antarctic ice sheet, Scherer (1991) noted that other diatoms known in the Recent but not the Pliocene are also present in his samples. These "late-Quaternary" diatoms are: Nitzschia separanda, Thalassiosira gracilis var. expecta, T. Antarctica and $T$. trifulta. Schrader (1976) recorded a lowest occurrence of Nitzschia separanda in DSDP site $324\left(69^{\circ}\right.$ $03.21^{\prime} \mathrm{S}, 98^{\circ} 47.20^{\prime} \mathrm{W}$ ) and assigned a late Pliocene age for this occurrence; however, based upon floral associations, a late Pliocene or early Pleistocene age is indicated. This cannot be considered a first occurrence, however, since the sample containing this species was recovered from a depth of approximately $106 \mathrm{~m}$ while the next sample examined below this (which did not contain $\mathcal{N}$. separanda) was recovered from a depth of c. $199 \mathrm{~m}$; in other words, more than $90 \mathrm{~m}$ of sediment below the lowest occurrence of $\mathcal{N}$. separanda was not examined by Schrader (1976). In North Pacific sediments, Sancetta (1985) found T. trifulta 
to be abundant back to about 800 kyear; it occurs before that time but her study did not extend further back. Its range in the Southern Ocean is not known. The geologic ranges of Thalassiosira gracilis var. expecta and T. antarctica have never been investigated, so it is not known how far back in time they ranged. Thus, with the exception of $\mathcal{N}$. separanda, these species are called Quaternary because their geologic record is not known. However, if it can be demonstrated conclusively that the first occurrence of these species in high southern latitudes took place during the late Quaternary, this may be taken as direct evidence that collapse occurred sometime during this time interval.

(3) If warm interglacials caused a collapse of the West Antarctic ice sheet, one would expect that, following collapse, warmer water would extend further southward over the region recently occupied by this feature; while this expectation may not be true for winter months, when sea ice may have covered the region, it will at least be so for spring and summer months. Since most Southern Ocean diatoms live within a temperature range of $-2^{\circ}$ to $8^{\circ} \mathrm{C}$ (Neori and Holm-Hansen, 1982; Burckle and others, 1987), one would also expect that those diatoms which survive in $>0^{\circ} \mathrm{C}$ water would, after ice-sheet collapse, extend their habitat southward. Nitzschia kerguelensis, for example, is one of the most ubiquitous open-ocean forms in the Southern Ocean today, being dominant in surface sediments (Burckle, 1984) as well as during the entire late Quaternary (i.e. from about 0.78 Myear to the present; see, for example, Donahue, 1967). Its present geographic range (Burckle and others, 1987) is from the Antarctic Slope Front $\left(0^{\circ} \mathrm{C}\right)$ to the sub-Antarctic Front $\left(8^{\circ} \mathrm{C}\right)$; in the Pacific sector, for example, it is common to abundant in surface waters from about $52^{\circ} \mathrm{S}$ southward to the northern part of the Ross Sea (Burckle and others, 1987). During the warmer-than-present early Holocene Climatic Optimum, however, it ranged into the Ross Sea south of the present Antarctic Slope Front (Kellogg and Truesdale, 1979). If the West Antarctic ice sheet collapsed in response to a warm interglacial during the late Quaternary, then the range of this species should have extended southward. It is not found, however, in Ice Stream B samples (Scherer, 1991). Similarly, the absence of Nitzschia curta from Ice Stream B samples should be questioned. This form is present and abundant (up to $80 \%$, for example, in the Ross Sea) in Holocene sediments of the shallow seas marginal to Antarctica and lives over a temperature range of $-2^{\circ}$ to $2^{\circ} \mathrm{C}$ (Burckle, 1984; see, also, references in Burckle and Pokras (1991)). In terms of temperature requirements, these two species are well suited to live in waters vacated by the West Antarctic ice sheet. Nitzschia kerguelensis is easily identifiable, even in fragments and $\mathcal{N}$. curta has dimensions similar to those pennate forms which were recovered from Ice Stream B samples. The argument that these two species were destroyed by abrasion is difficult to sustain when one considers that larger centric forms recovered from beneath Ice Stream B were not (Scherer, 1991; pl. 1-3).

(4) Scherer (1991) noted that the "apparent lack of Pliocene and early Pleistocene diatoms beneath Ice Stream B is probably a result of low net-biogenic accumulation during the Plio-Pleistocene, coupled with the erosional effects of repeated grounding-line advances across the sea floor'. However, this has not been demonstrated. If one considers sites occupied by ODP leg 113 in the Weddell Sea (near the continent), highest sedimentation rates (consisting largely of biosiliceous sediments) occurred in the Pliocene. In site 693 $\left(70^{\circ} 49.9^{\prime} \mathrm{S}\right)$, Lower Pliocene sedimentation rates were on the order of $60 \mathrm{~m} \mathrm{Myear}^{-1}$ as opposed to $16 \mathrm{~m} \mathrm{Myear}^{-1}$ for the Quaternary. In site $695\left(62^{\circ} \mathrm{S}\right)$, the Lower Pliocene sedimentation rate was on the order of 170 $250 \mathrm{~m} \mathrm{Myear}^{-1}$, while Upper Pliocene rates were on the order of $35 \mathrm{~m} \mathrm{Myear}^{-1}$ (all data noted above are taken from Gersonde and others (1990)).

(5) Scherer (1991) pointed out that "The presence of freshwater diatomite clasts in the till provides evidence of large lake systems in West Antarctica during the Cenozoic, possibly the Neogene". The presence of large lake systems cannot be substantiated on the basis of reworked clasts containing fresh-water diatoms. The diatom Aulocoseria sp. A (member of the Aulocoseria italica group of Simonsen (1979)) is fresh-water but its presence in Ice Stream B samples does not necessarily indicate a system of large lakes on West Antarctica. The genus is found in great abundance (both in sediments and in the water column) in the annual lakes of the Sahelian region of Africa. These lakes are fed by summer rains but often dry completely during the northern winter (Flohn, 1965; Flohn and Nicholson, 1980). Similarly, small, deep lakes, or one small deep lake, can support members of this genus; it does not necessarily have to be large nor does it have to be an extensive lake system.

\section{DISCUSSION}

From my perspective, there is as yet no direct evidence to support the contention that the West Antarctic ice sheet collapsed sometime during the late Quaternary. I make this comment even though I am aware of data from continents, ice cores and the deep sea which suggest that some late Quaternary interglacials were warmer than the Holocene and that some of these time intervals may have witnessed sea-level stands higher than the present. Although such data suggest an ice-sheet response, they do not implicate any particular ice sheet. Furthermore, in view of the fact that dynamic ice sheets and the processes accompanying such ice sheets (i.e. smearing and reworking, sediment removal, flushing through basal meltwater channels, bottom freeze-on, etc.) generally do not preserve stratigraphically acceptable sediment records beneath them, it would be futile to use microfossils in such sediments to develop an ice-sheet history. Microfossils recovered from such sediments (as well as the nonoccurrence of microfossils) will always be the subject of controversy and debate. Rather, I suggest that the micropaleontologist/paleoceanographer can best contribute to the question of late Quaternary ice-sheet stability/ instability by study of deep-sea sediments around the Antarctic continent.

I admit that this is a very parochial viewpoint, because it suggests that my way is better. However, if collapse occurred, such an approach would better help to 
clarify the mechanism and timing of failure. I am aware of two general models for the West Antarctic ice sheet which incorporate collapse. One, which I refer to as the standard model, calls for collapse of this feature in response to interglacial warming. Implicit in this model is the view that warming and collapse occurred within the same interglacial interval. The second model is that recently proposed by MacAyeal (1992) in which ice-sheet collapse is irregular in time and is due in large part to the "slow-equilibration time of the distribution of basal till, which lubricates ice-sheet motion" (MacAyeal, 1992). Both of these models are amenable to testing in deep-sea sediments; the former by analysis of temporal and spatial distribution of temperature-dependent siliceous and calcareous microfossils and the latter by identification and analysis of abrupt, sporadic and massive occurrences of ice-rafted particles in deep-sea sediments recovered downstream from the West Antarctic ice sheet. Preliminary analysis of Southern Ocean deep-sea data bearing on the standard model suggests that collapse did not occur during any late Quaternary interglacials. However, I stress that such data are preliminary and should not be the subject of newspaper reports or policy decisions. As yet, there are only limited Southern Ocean deep-sea data bearing on the MacAyeal (1992) model. Such limited data suggest (but do not prove) that periodic collapse (or draw-down) of the West Antarctic ice sheet may have occurred during the late Quaternary. However, if this is true, then draw-down occurred at more frequent intervals than the time-table proposed by MacAyeal (1992). As with the standard model, the same restrictions regarding the use of such limited data apply.

\section{ACKNOWLEDGEMENTS}

This paper has been improved by discussions with $\mathbf{T}$. Guilderson, W. Howard, S. Rudolph and S. Jacobs; however, any brickbats that accrue from this paper should be directed solely at the author. Indeed, brickbats are welcome provided they contain data. I thank the Editor of the Fournal of Glaciology for the opportunity to present my views. Research support was provided by U.S. National Science Foundation grant DPP91-18995. This is Lamont-Doherty Earth Observatory Contribution No. 5047.

\section{REFERENCES}

Abbott, W.H. 1974. Temporal and spatial distribution of diatoms from the southeast Indian Ocean. Nova Hedwigia, 25, 291-346.

Abelmann, A., R. Gersonde and V. Spiess. 1990. Pliocene-Pleistocene paleoceanography in the Weddell Sea-siliceous microfossil evid- ence. In Bleil, U. and J. Thiede, eds. Geological history of the polar oceans: Arctic versus Antarctic. Dordrecht, etc., Kluwer Academic Publishers, 729-759.

Baldauf, J.G. and J.A. Barron. 1991. Diatom biostratigraphy: Kerguelen Plateau and Prydz Bay regions of the Southern Ocean. Ocean Drilling Program. Proceedings. Scientific Reports B 119, 547-598.

Burckle, L. H. 1984. Diatom distribution and oceanographic reconstruction in the Southern Ocean - present and last glacial maximum. Marine Micro-palaeontology, 9, 241-262.

Burckle, L. H. and E. M. Pokras. 1991. Implications of a Pliocene stand of Nothofagus (southern beech) within 500 kilometres of the South Pole. Antarct. Sci., 3(4), 398-403.

Burckle, L. H., S. S. Jacobs and R. M. McLaughlin. 1987. Late spring diatom distribution between New Zealand and the Ross Sea: correlation with hydrography and bottom sediments. Micropaleontology, 33, 77-81.

Ciesielski, P.F. 1983. The Neogene and Quaternary diatom biostratigraphy of subantarctic sediments. Deep Sea Drilling Project. Initial Reports 71, 625-691.

Domack, E.W., A.J.T. Jull and S. Nakao. 1991. Advance of East Antarctic outlet glaciers during the Hypsithermal: implications for the volume state of the Antarctic ice sheet under global warming. Geology, 19(11), 1059-1062.

Donahue, J.G. 1967. Diatoms as indicators of Pleistocene climatic fluctuations in the Pacific sector of the Southern Ocean. In Heezen, B. C., ed. Progress in oceanography. Vol. 4. The Quaternary history of the ocean basins. New York, Pergamon Press, 133-140.

Flohn, H. 1965. Warum ist die Sahara trocken? Z. Meteorol., 17, 316320.

Flohn, H. and S. Nicholson. 1980. Climatic fluctuations in the arid belt of the "Old World" since the last glacial maximum: possible causes and future implications. Palaeoecol. Afr., 12, 3-12.

Gersonde, R. and L. H. Burckle. 1990. Neogene diatom biostratigraphy of ODP Leg 113, Weddell Sea (Antarctic Ocean). Ocean Drilling Program. Proceedings. Scientific Results 113, 761-789.

Gersonde, R. and 8 others. 1990. Biostratigraphic synthesis of Neogene siliceous microfossils from the Antarctic Ocean, ODP Leg 113 (Weddell Sea). Ocean Drilling Program. Proceedings. Scientific Results $113,915-936$.

Harwood, D. M. and T. Maruyama. 1992. Middle Eocene to Pleistocene diatom biostratigraphy of Southern Ocean sediments from the Kerguelen Plateau, Leg 120. Ocean Drilling Program. Proceedings. Scientific Results 120, 683-733.

Kellogg, T. B. and R.S. Truesdale. 1979. Late Quaternary paleoecology and paleoclimatology of the Ross Sea: the diatom record. Marine Micropalaeontology, 4, 137-158.

MacAyeal, D. 1992. Irregular oscillations of the West Antarctic ice sheet. Nature, 359(6390), 29-32.

Mercer, J. 1978. West Antarctic ice sheet and $\mathrm{CO}_{2}$ greenhouse effect: a threat of disaster. Nature, 27(5643), 321-325.

Neori, A. and O. Holm-Hansen. 1982. Effect of temperature on rate of photosynthesis in Antarctic phytoplankton. Polar Biol., 1(1), 33-38.

Sancetta, C. 1985. Late Pleistocene (Brunhes) diatom record at site 580. Deep Sea Drilling Project. Initial Reports 86, 423-427.

Scherer, R.P. 1991. Quaternary and Tertiary microfossils from beneath Ice Stream B: evidence for a dynamic West Antarctic ice sheet history. Palaeogeogr., Palaeoclimatol., Palaeoecol., 90(4), 395-412.

Schrader, H. -J. 1976. Cenozoic planktonic diatom stratigraphy of the southern Pacific Ocean. Deep Sea Drilling Project. Initial Reports 35, $605-671$.

Simonsen, R. 1979. The diatom system: ideas on phylogeny. Bacillaria, 2, 9-71.

The accuracy of references in the text and in this list is the responsibility of the author, to whom queries should be addressed. 